\title{
The Influence of Employee Competency and Career Management on Career Commitment: Regional Government in Indonesia
}

\author{
Juliansyah NOOR ${ }^{1}$, Agus SUHERLI ${ }^{2}$, Ade Jaya SUTISNA ${ }^{3}$
}

Received: September 10, 2020 Revised: November 08, 2020 Accepted: November 16, 2020

\begin{abstract}
This study aims to test the influence of employee competency and career management on career commitment in Indonesia. The study uses the cross-sectional data of regional government employees collected from February to April 2020. Regression and structural equation modeling are employed. The results base on the effect of employee competency and career management on career commitment in Indonesia are in line with the existing theory (i.e., Bandura's Career Theory). Employee competency has a significant positive influence on career management and career commitment, which shows that regional government employees with high competency generate effective career management, and in turn career commitment increased. Regional governments with their career management program should formulate human resources management practice policy (e.g., career support, training, career development program, and orientation programs) in order to increase their competency. The positive effect of employee competency on career management is because of the effective training and career development program. The positive influence of career management on career commitment is due to the regional government providing an attractive career program, thus, employees' career commitment improved. The positive influence of employee competency on career commitment via career management is implemented by regional government support to improve the career management program.
\end{abstract}

Keywords: Employee Competency, Career Management, Career Commitment, Regional Government

JEL Clasification Code: M10, M12, M19

\section{Introduction}

This study on career management and career commitment is aimed to confirm the human resources management practice and organizational behavior theory. Career commitment refers to a person's professional attitude at work (Blau, 1985). Blau (1985) reports that a person can identify his profession (job position, job tenure, job title, training, and education) to obtain relevant competency with his/her job. Prior studies have confirmed that individuals

${ }^{1}$ First Author and Corresponding Author. Associate Professor, Management Department, STIE La Tansa Mashiro, Indonesia [Postal Address: Jl. Soekarno - Hatta, Lebak, Banten, 42317, Indonesia]

Email: profjul.noor@gmail.com

${ }^{2}$ Assistant Lecturer, Management Department, STIE La Tansa Mashiro, Indonesia. Email: pakidulanagus1008@gmail.com

${ }^{3}$ Assistant Professor, Management Department, STIE La Tansa Mashiro, Indonesia. Email: adejayasutisna1@gmail.com

(c) Copyright: The Author(s)

This is an Open Access article distributed under the terms of the Creative Commons Attribution Non-Commercial License (https://creativecommons.org/licenses/by-nc/4.0/) which permits unrestricted non-commercial use, distribution, and reproduction in any medium, provided the original work is properly cited. are committed to his/her career by developing skills (Blau, 1989), competency (Zhang, Zhang, \& Li, 2018), and career management (Vinkenburg \& Weber, 2012). Furthermore, Mcketin, Livingston, Chalmers, \& Bright (2014) report evidence of competency as an important dimension in career commitment.

The present study examines the influence of employee competency on career management and career commitment from employee perception of regional government in Indonesia. This study focuses on Indonesia, which has the most regional governments in Southeast Asia since relatively few studies have investigated the influence of employee competency on career management and career commitment. Moreover, the results are inconsistent. Zhang et al. (2018) found that employee competency has no effect on career commitment. Kong, Cheung, and Song (2012) suggested that employee competency affects career management and career commitment. Fu (2011) found that career management is affected by career commitment in Taiwan companies. Others (Lent \& Brown, 2013; Conway, MichaelL, Sturges, \& Budjanovcanin, 2015) also show the role of career management as a mediator in the effect of employee competency on career commitment. 
Career management for regional government employees is different from the private firm. A noticeable difference is that regional government employees follow self-careers and they usually apply mobility of career strategies to carry on their careers (Brown, Bimrose, Barnes, \& Hughes, 2012; Nguyen, Ha, \& Dang, 2020); consequently, career development for regional government employees tend to be better than the private firm. Ng and Feldman, (2014) argued that the employee competency improvement and managing self-career development determine the career management program in Indonesia.

From the above description, examining the influence of employee competency on career management and career commitment at the regional government in Indonesia is essential. The present study contributes to the extant literature by focusing on the human resources practice of regional government in Indonesia, the country with the largest number of regional governments in Southeast Asia.

\section{Literature Riview}

\subsection{Bandura' Career Theory}

Social cognitive career theory (SCCT) is a networkbased social cognitive theory that focuses primarily on cognitive and contextual factors (Bandura, 1997). It aims to track relations between individuals and their careers (Liguori, Bendickson, \& McDowell, 2018). Bandura (1997) believes that SCCT can affect their own developments and environments (e.g., society is filled with constructive, independent, self-reflective citizens with the ability to influence their own decisions for certain outcomes). Furthermore, Bandura (1999) states that an individual has the ability to regulate one's own perception, motivation, power, and action based on personal mechanisms. How individuals perceive the consequences of their actions inform and change both their perception of their environment and the cognitive factors (e.g., domain-specific, self-efficacy, etc.); they can, thus, alter their actions (Luc, 2020).

\subsection{Relationship Between Employee Competency and Career Commitment}

Career commitment is generally described as extrinsic and intrinsic motivation of career choice measured with using objective and subjective indicators (Blau, 1985; Guan, Arthur, Khapova, Hall, \& Lord, 2019). Objective indicators show an external perspective that describes an individual's career situation, salary, promotion, and job level (Sidani \& Al Hakim, 2012). Meanwhile, subjective indicators are defined as feelings of achievement and individual commitment to their careers (Thomas, Lillian, Kelly, \& Daniel, 2005). The influence of employee competency on career commitment is well established in the current literature (Guan et al., 2019; Park, 2020).

$\mathrm{Fu}$ (2011) describes that employee competency can influence career commitment through employee perception of competencies. Such employees increase the competency of their job and enhance career commitment through career identify, career involvement, and career investment. Individual perception of employee competency positively influences career commitment (Wilson, Liddell, Hirschy, \& Pasquesi, 2016; Bagdadli and Gianecchini, 2019). Below is the following hypothesis:

H1: Employee competency has a positive influence on career management in Indonesia.

\subsection{Relationship Between Career Management and Career Commitment}

Career management is important for developing individual career among employees (Campion, Cheraskin, \& Stevens, 1994). The role of career management in enhancing career commitment is manifested by employees' perceived job engagements and, thus, their increased career (Burke \& McKeen, 1995). For example, when employees are given training, career support, and challenging jobs of the career intensify. Career management develops an employee's trust in the organization and becomes more creative and innovative. Such career management positively shapes employees' perceptions of their career support, training, career development program, and eventually leads to improving career commitment.

Career management can be viewed as an organizational initiative to give a chance to employees for developing self-career and resolving formal barriers in organizations (Armstrong-Stassen \& Ursel, 2009). It is believed that employees must often upgrade their knowledge and abilities through networking, thus, the resolving formal barriers are important. Organizations that develop employee careers by improving knowledge and abilities with their employees will increase their career (Vinkenburg \& Weber, 2012; Hirschi, 2012). In the present study, we formulated the following hypothesis:

H2: Career management has a positive influence on career commitment in Indonesia.

\subsection{Relationship Between Employee Competency and Career Management}

Organizations play a major role in career management activities in the modern market climate, as advocates and creators of human assets (Baruch, 2006). Past studies suggest that Hirschi's (2012) three characteristics of employee 
competency - "knowing how" as career skill and job knowledge; "knowing why" as identification, motivation, and individual meaning; "knowing whom" as job-related and networking - serve as predictors to career management in organizations. In other words, these characteristics are valued universal elements of employee competency to career in the workplace. A similar argument can be established both theorical and empirical. Past studies have indicated that employee competency has a positive influence on career management (Ng \& Feldman, 2014; Kong, Cheung, \& Zhang, 2010; Sumaryati, Novitasari, \& Machmuddah, 2020). Thus, we can state the hypothesis as a following:

H3: Employee competency has a positive influence on career management in Indonesia.

\subsection{Mediating Variable: Career Management}

In addition to its direct effect on career commitment, the influence of employee competence on career commitment can be mediated by career management. The function of the mediator is a generative mechanism by which the independent variable may influence the dependent variable. (Hayes, 2018). Career management is an essential job resource that helps staff to efficiently control their jobs. (Cerdin \& Pargneux, 2010; Hirschi, Niles, \& Akos, 2011). Thus, employees with adequate career management at work tend to have high career commitment (Ito \& Brotheridge, 2005; Katz, Rudolph, \& Zacher, 2019). Moreover, organizations that manage employees career effectively can improve employee competence (Kang, Gatling, \& Kim, 2015) and increase career commitment to remain in the current organization ( $\mathrm{Ng} \&$ Sorensen, 2008). In the present study, we formulated the following hypothesis:

H4: Employee competency has a positive influence on career management through career management in Indonesia.

Furthermore, we constructed the research model based on the hypotheses presented regarding employee competency, career management, and career commitment (Figure 1). The model shows that career management is a mediator that strengthens the effect of employee competency on career commitment.

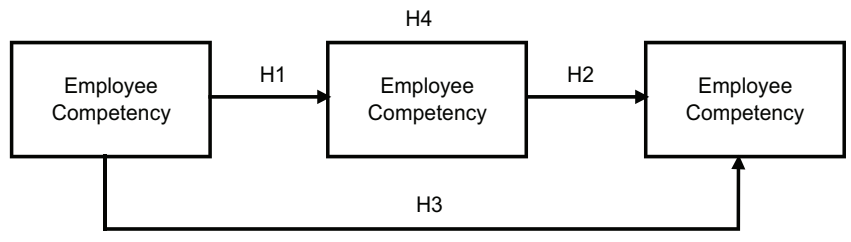

Figure 1: Research Model

\section{Methodology}

\subsection{Sample and Survey}

This study focuses on the regional government in Banten Province, Indonesia. This sample is drawn from all regional governments in Banten, both city and regency. This study employs primary data collected through an online survey utilizing Google Form, which allows researchers to design surveys and questionnaires, distributed directly to respondents at regional government in Banten, Indonesia from February to April, 2020. The population in the study is all employees (echelon IV) at the regional government in Banten, such as the supervisor and other section heads. This study employs a purposive sample to choose respondents subjectively.

\subsection{Data Analysis}

We did an analysis to assess the contributions of an independent variable (employee competency) to dependent variables (career management and career commitment). The analysis process includes three main steps (Jöreskog, Olsson, \& Wallentin, 2016). First, Construct reliability and Confirmatory Factor Analysis (CFA) is implemented to assess the reliability of variables. Second, measurement models to evaluate scales. finally, the structural model to test hypotheses and assess the level of significance. Furthermore, the statistical analysis is employing SPSS 25.0 and Lisrel 8.7

\subsection{Measurements}

All of the scales in our study were adapted from prior studies. Scales were scored on a five-point format of Linkert, from (1) "strongly disagree" to (5) "strongly agree".

Employee competency (construct realibility $=0.78$ ); the instrument arranged by De Vos, De Hauw, and Van der Heijden (2011) uses five items: "My boss regularly gives me feedback about my performance" (0.87); "My organization provides new and creative training opportunities" $(0.77)$; "My boss makes sure that I can learn on the job by giving me challenging assignments" $(0.81)$; "My colleagues regularly give me feedback about my performance" (0.78); and "My boss makes sure that I develop the competencies that I need for my career" (0.83).

Career management (construct reliability $=0.83$ ); the scale developed by De Oliveira, Cavazotte, and Alan Dunzer (2019) uses five items: "I have opportunities to formally discuss career decisions with my leader" (0.82); "I informally talk about my career issues with my leader" (0.77); "I receive regular feedback about my development from my leader" (0.92); "My leader makes efforts to enrich my work with activities relevant for my career" $(0.71)$; and "My leader helps me planning my career" (0.82). 
Career commitment (construct reliability $=0.89$ ); the scale developed by $\mathrm{Fu}$ (2011) uses five items: "I am satisfied with the success I have achieve in my career" ( 0.83$)$; "It will be difficult for me to change to another career" (0.75); "I invested a lot in my professional career" (0.91); "I invested job tenure in my professional career" $(0.68)$; and "I invested length of service in my professional career" $(0.85)$.

\section{Results}

\subsection{Descriptive statistics}

The 267 respondents survey indicates that the sample of employee competency, the influence of career management, and career commitment in Indonesia is mainly female $(67.2 \%)$, nearly twice as as male $(32.8 \%)$; most of them are between the age of 31 and $40(72.5 \%)$; respondents are college/university educated $(78.5 \%)$; the job tenure is mostly $5-10$ years $(71.5 \%)$, followed by job tenure of more than 10 years $(28.5 \%)$; finally, the education division accounts for $45.5 \%$ of respondents, one-stop service division $(42.0 \%)$, and others $(15.5 \%)$.

\subsection{Measurement Model}

The measurement model results from the sample with $\chi 2=315.70 ; \mathrm{df}=123 ; \mathrm{RMSEA}=0.007 \leq 0.08 ; \mathrm{CFI}=0.932$ $\geq 0.90$; NFI $=0.976 \geq 0.90$. Hence, the estimated results show that the model of indicators is suitable for the data. The results of testing scales by measurement model indicated that the loading factor of indicators for the concepts describe in Table 1, all loading factors have significance level $(\rho<$ 0.000 ); the values of the standardized weights are $>0.5$, thus, the scales achieve the convergence value (Hair et al., 2018; Fornell \& Larcker, 1994). However, the subjective norm has the composite reliability of 0.75 (employee competency), 0.78 (career management), and 0.86 (career commitment) more than 0.70 . Total variance extracted is 0.64 (employee competency), 0.61 (career management), and 0.68 (career commitment) more than 0.5 , showing that the survey data account for $64 \%$ of the relationship between employee competency indicators; $61 \%$ of the relationship between career management indicators; and $68 \%$ of the relationship between career commitment indicators. Means, standard deviations, and correlations of variables are shown in Table 2.

Table 1: Measurement Model Results

\begin{tabular}{|c|c|c|c|c|}
\hline Variable & Mean & $\begin{array}{c}\text { factor } \\
\text { loadings }\end{array}$ & $\begin{array}{l}\text { Composite } \\
\text { reliability }\end{array}$ & $\begin{array}{l}\text { Average } \\
\text { variance } \\
\text { extracted }\end{array}$ \\
\hline \multicolumn{5}{|l|}{ Career Commitment } \\
\hline $\begin{array}{l}\text { - "I am satisfied with the success I have achieve in my career" } \\
\text { - "It will be difficult for me to change to another career" } \\
\text { - "I invested a lot in my professional career" } \\
\text { - "I invested job tenure in my professional career" } \\
\text { - "I invested length of service in my professional career" }\end{array}$ & $\begin{array}{l}4.23 \\
4.17 \\
4.34 \\
4.40 \\
4.10\end{array}$ & $\begin{array}{l}0.86 \\
0.83 \\
0.76 \\
0.78 \\
0.85\end{array}$ & 0.83 & 0.68 \\
\hline \multicolumn{5}{|l|}{ Employee Competency } \\
\hline $\begin{array}{l}\text { - "My boss regularly gives me feedback about my performance" } \\
\text { - "My organization provides new and creative training opportunities" } \\
\text { - "My boss makes sure that I can learn on the job by giving me } \\
\text { challenging assignments" } \\
\text { - "My colleagues regularly give me feedback about my performance" } \\
\text { - "My boss makes sure that I develop the competencies that I need for } \\
\text { my career" }\end{array}$ & $\begin{array}{l}3.72 \\
4.16 \\
3.86 \\
3.62 \\
4.47\end{array}$ & $\begin{array}{l}0.78 \\
0.85 \\
0.82 \\
0.72 \\
0.79\end{array}$ & 0.86 & 0.72 \\
\hline \multicolumn{5}{|l|}{ Career Management } \\
\hline $\begin{array}{l}\text { - "I have opportunities to formally discuss career decisions with my } \\
\text { leader" } \\
\text { - "I informally talk about my career issues with my leader" } \\
\text { - "I receive regular feedback about my development from my leader" } \\
\text { - "My leader makes efforts to enrich my work with activities relevant } \\
\text { for my career" } \\
\text { - "My leader helps me planning my career" }\end{array}$ & $\begin{array}{l}4.20 \\
4.32 \\
4.45 \\
4.37 \\
4.32\end{array}$ & $\begin{array}{l}0.73 \\
0.78 \\
0.74 \\
0.84 \\
0.77\end{array}$ & 0.79 & 0.65 \\
\hline
\end{tabular}

Notes: Five measurement items of employee competency, career management, and career commitment. 


\subsection{Structural Model}

Structure model results from the sample with $\chi^{2}=$ $156.28 ; \mathrm{df}=38 ;$ RMSEA $=0.017 \leq 0.08 ;$ CFI $=0.921 \geq$ $0.90 ; \mathrm{NFI}=0.956 \geq 0.90 ; \mathrm{GFI}=0.912>0.90$. Thus, structure model analysis (Table 3) indicates that:

- Employee competency with a beta $(\beta)$ of 0.18 has the weakest positive significant $(\mathrm{t}$-value $=2.14>1.96)$ influence on career commitment.

- Career management with a beta $(\beta)$ of 0.40 has a moderate influence positive significant $(\mathrm{t}$-value $=8.71>1.96)$ on career commitment.
- Employee competency with a beta $(\beta)$ of 0.48 has the strongest positive significant $(\mathrm{t}$-value $=9.72>1.96)$ influence on career management.

- Employee competency with a beta $(\beta)$ of 0.19 has influenced positively on career commitment through career management. Thus, career management as a mediating variable was full mediation due to the indirect effect of employee competency on career commitment through career management $(\beta=0.19)$ more than the direct effect of employee competency on career commitment $(\beta=0.18)$.

Thus, H1, H2, H3, and $\mathrm{H} 4$ are supported.

Table 2: Means, Standard Deviations, and Correlations

\begin{tabular}{|l|c|c|c|c|c|}
\hline Variables & Mean & SD & Career Commitment & Employee Competency & Career Management \\
\hline Career Commitment & 4.15 & 0.36 & - & - & - \\
\hline Employee Competency & 3.62 & 0.49 & $0.293^{* * *}$ & - & - \\
\hline Career management & 3.67 & 0.41 & $0.436^{\star * *}$ & $0.385^{\star * *}$ & - \\
\hline
\end{tabular}

Note: $\mathrm{N}=267$, one tail test ${ }^{* * *} \rho<0.001$.

Table 3: Straucture Model Results

\begin{tabular}{|l|l|c|c|c|}
\hline Hypothesis & \multicolumn{1}{|c|}{ Path Model } & Beta & t-value & Results \\
\hline H1 & Employee competency $\rightarrow$ Career commitment & 0.18 & 2.14 & Supported \\
\hline H2 & Career management $\rightarrow$ Career commitment & 0.40 & 8.71 & Supported \\
\hline H3 & Employee competency $\rightarrow$ Career management & 0.48 & 9.72 & Supported \\
\hline H4 & $\begin{array}{l}\text { Employee competency } \rightarrow \text { Career } \\
\text { management } \rightarrow \text { Career commitment }\end{array}$ & 0.19 & 3.73 & Suppported \\
\hline
\end{tabular}

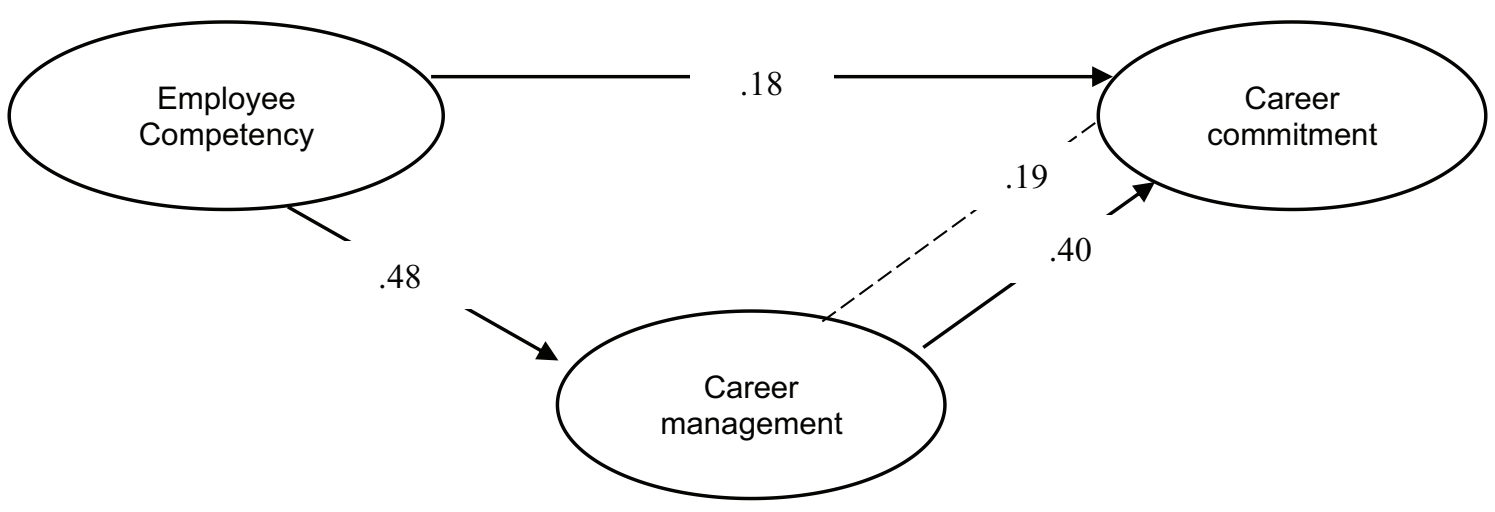

Figure 2: Structural Model Result 


\section{Discussion and Limitation}

\subsection{Discussion}

Employee competency positively influences career commitment. This study also supports prior studies. Guan et al. (2019) indicate that employee competency affects career commitment. It means that organizations' support for individual career development has a positive effect on employee competency development. Thus, employee competency is also an important part of the management of human resources.

Career management has a positive influence on career commitment, which has been empirically supported. This study also supports the past study. Bagdadli and Gianecchini (2019) show that career management makes the greatest contribution to career commitment. Thus, it can be concluded that more effective career management, improve career commitment. The results of this research are consistent with some previous studies (Thomas et al., 2005; ArmstrongStassen \& Ursel, 2009).

Employee competency has a positive effect on career management. Employee competency influences career development activities and career aspirations (De Vos \& Cambre, 2016; Koch \& Forgues, 2015). Thus, the findings show that, with the increasing employee competency, the more likely organizations have effective career management. This result supports Yang, Nam-Young, and Han, (2010) who argued that employee competency affects career management.

Employee competency positively influences career commitment through career management. This study investigates the effect of mediation to identify whether the relationship between employee competence and career commitment in the regional government employees studied is mediated by career management. The findings suggest that the indirect effect is significant and full mediating occurs; it means that career management strengthened the effect of employee competency on career commitment. This study is in line with the theory of Tomlinson, Baird, Berg, and Cooper (2018).

\section{Conclusion}

These study findings support the theory of direct effect. First, the direct effect of employee competency on career management and career commitment indicates a significant effect. This shows that the improvement of employee competency increases the career management and career commitment. Career management affects career commitment positively and significantly. This indicates that the more effective career management, the greater career commitment. These empirical findings show that career management acts as a mediator between employee competency and career commitment to the regional government in Indonesia.

\subsection{Limitation}

This study has several limitations. Firstly, the scope of the study is regional government employees in Indonesia. However, the respondents mainly surveyed were between the ages of 24 and 45 and did not include respondents in other age groups. Therefore, the sample does not represent all regional government employees in Indonesia. Secondly, we conducted a survey of regional government employees with a purposive sampling method, thus, it was hard to get a high level of representation. Thirdly, the career commitment variable is also affected by many other variables besides employee competency and career management. Therefore, future research needs to investigate other organizational behavior variables such as trust, good governance, and leadership performance.

\section{References}

Armstrong-Stassen, M., \& Ursel, N. D. (2009). Perceived organizational support, career satisfaction, and the retention of older workers. Journal of Occupational and Organizational Psychology, 82(1), 201-220. https://doi. org/10.1348/096317908X288838

Bagdadli, S., \& Gianecchini, M. (2019). Organizational career management practices and objective career success: Asystematic review and framework. Human Resource Management Review, 29(3), 353-370. https://doi.org/10.1016/j.hrmr.2018.08.001

Bandura, A. (1997). Theoretical Perspectives: the nature of human agency. Self-Efficacy: The Exercise of Control. https://doi. org/10.1007/SpringerReference_223312

Bandura, A. (1999). Social Cognitive Theory: An Agentic Perspective. Asian Journal of Social Psychology, 2(1), 21-41. https://doi.org/https://doi.org/10.1111/1467-839X.00024

Baruch, Y. (2006). Career development in organizations and beyond: Balancing traditional and contemporary viewpoints. Human Resource Management Review, 16(2), 125-138. https:// doi.org/10.1016/j.hrmr.2006.03.002

Brown, A., Bimrose, J., Barnes, S. A., \& Hughes, D. (2012). The role of career adaptabilities for mid-career changers. Journal of Vocational Behavior, 80(3), 754-761. https://doi.org/10.1016/j. jvb.2012.01.003

Burke, R. J., \& McKeen, C. A. (1995). Do Managerial Women Prefer Women Mentors? Psychological Reports, 76(2), 688690. https://doi.org/10.2466/pr0.1995.76.2.688

Campion, M. A., Cheraskin, L., \& Stevens, M. J. (1994). CareerRelated Antecedents and Outcomes of Job Rotation. Academy of Management Journal, 37(6), 1518-1542. https://doi. org/10.5465/256797

Cerdin, J.-L., \& Pargneux, M. Le. (2010). Career Anchors: A Comparison Between Organization-Assigned and Self-Initiated Expatriates. Thunderbird International Business Review, 52(4), 287-299. https://doi.org/https://doi.org/10.1002/tie.20350 
Conway, N., MichaelL, C., Sturges, J., \& Budjanovcanin, A. (2015). Using self-determination theory to understand the relationship between calling enactment and daily well-being. Journal of Organizational Behavior, 36(8), 1114-1131. https://doi.org/ https://doi.org/10.1002/job.2014

de Oliveira, L. B., Cavazotte, F., \& Alan Dunzer, R. (2019). The interactive effects of organizational and leadership career management support on job satisfaction and turnover intention. International Journal of Human Resource Management, 30(10), 1583-1603. https://doi.org/10.1080/09585192.2017.1 298650

De Vos, A. \& Cambre, B. (2016). Career Management in HighPerforming Organizations: A Set-Theoretical Approach. Human Resource Management, 45(1), 127-145. https://doi. org $/ 10.1002 / \mathrm{hrm}$

De Vos, A., De Hauw, S., \& Van der Heijden, B. I. J. M. (2011). Competency development and career success: The mediating role of employability. Journal of Vocational Behavior, 79(2), 438-447. https://doi.org/10.1016/j.jvb.2011.05.010

Fu, J. R. (2011). Understanding career commitment of IT professionals: Perspectives of push-pull-mooring framework and investment model. International Journal of Information Management, 31(3), 279-293. https://doi.org/10.1016/j. ijinfomgt.2010.08.008

Gary J. Blau. (1985). The measurement and prediction of career commitment. Journal of Occupational Psychology, 58(1983), $277-288$.

Gary J. Blau. (1989). Testing the Generalizability of a Career Commitment Measure and Its Impact on Employee Turnover. Journal of Vocational Behavior, 35, 88-103.

Guan, Y., Arthur, M. B., Khapova, S. N., Hall, R. J., \& Lord, R. G. (2019). Career boundarylessness and career success: A review, integration and guide to future research. Journal of Vocational Behavior, 110, 390-402. https://doi.org/10.1016/j. jvb.2018.05.013

Hayes, A. F. (2018). Introduction to Mediation, Moderation, and Conditional Process Analysis: A Regression-Based Approach. New York, NY: Guilford Publication.

Hirschi, A. (2012). The career resources model: An integrative framework for career counsellors. British Journal of Guidance and Counselling, 40(4), 369-383. https://doi.org/10.1080/0306 9885.2012.700506

Hirschi, A., Niles, S. G., \& Akos, P. (2011). Engagement in adolescent career preparation: Social support, personality and the development of choice decidedness and congruence. Journal of Adolescence, 34(1), 173-182. https://doi.org/10.1016/j. adolescence.2009.12.009

Ito, J. K., \& Brotheridge, C. M. (2005). Does supporting employees' career adaptability lead to commitment turnover, or both? Human Resource Management, 44(1), 5-19. https://doi. org/10.1002/hrm.20037

Jöreskog, K. G., Olsson, U. H., \& Wallentin, F. Y. (2016). Multivariate Analysis with LISREL. In: P. Bickel, P. Diggle, S. E.
Fienberg, U. Gather, \& S. Zeger (Eds.), Springer International Publishing (Vol. 34). Cham, Switzerland: Springer. https://doi. org/10.1007/978-3-319-33153-9

Kang, H. J., Gatling, A., \& Kim, J. (2015). The Impact of Supervisory Support on Organizational Commitment, Career Satisfaction, and Turnover Intention for Hospitality Frontline Employees. Journal of Human Resources in Hospitality and Tourism, 14(1), 68-89. https://doi.org/10.1080/15332845.201 4.904176

Katz, I. M., Rudolph, C. W., \& Zacher, H. (2019). Age and career commitment: Meta-analytic tests of competing linear versus curvilinear relationships. Journal of Vocational Behavior, 112(March), 396-416. https://doi.org/10.1016/j. jvb.2019.03.001

Kong, H., Cheung, C., \& Song, H. (2012). From hotel career management to employees' career satisfaction: The mediating effect of career competency. International Journal of Hospitality Management, 31(1), 76-85. https://doi.org/10.1016/j. ijhm.2011.03.002

Kong, H., Cheung, C., \& Zhang, H. (2010). Career management systems: what are China's state-owned hotels practising? InternationalJournalofContemporaryHospitalityManagement, 22(4), 467-482. https://doi.org/10.1108/09596111011042695

Lent, R. W., \& Brown, S. D. (2013). Social cognitive model of career self-management: Toward a unifying view of adaptive career behavior across the life span. Journal of Counseling Psychology, 60(4), 557-568. https://doi.org/10.1037/a0033446

Liguori, E. W., Bendickson, J. S., \& McDowell, W. C. (2018). Revisiting entrepreneurial intentions: a social cognitive career theory approach. International Entrepreneurship and Management Journal, 14(1), 67-78. https://doi.org/10.1007/ s11365-017-0462-7

Luc, P. T. (2020). Outcome expectations and social entrepreneurial intention: Integration of planned behavior and social cognitive career theory. Journal of Asian Finance, Economics and Business, 7(6), 399-407. https://doi.org/10.13106/jafeb.2020. vol7.no6.399

Michael Koch, Bernard Forgues, A. V. M. (2015). The Way To The Top: Career Patterns of Fortune 100 CEOs. Human Resource Management, 56(2), 267-285. https://doi.org/10.1002/hrm

Ng, T. W. H., \& Feldman, D. C. (2014). Subjective career success: A meta-analytic review. Journal of Vocational Behavior, 85(2), 169-179. https://doi.org/10.1016/j.jvb.2014.06.001

Ng, T. W. H., \& Sorensen, K. L. (2008). Toward a further understanding of the relationships between perceptions of support and work attitudes: A meta-analysis. Group and Organization Management, 33(3), 243-268. https://doi. org/10.1177/1059601107313307

Nguyen, D. T., Ha, V. D., \& Dang, T. T. N. (2020). The impact of human resource management activities on the compatibility and work results. Journal of Asian Finance, Economics and Business, 7(9), 621-629. https://doi.org/10.13106/jafeb.2020. vol7.no9.621 
Park, Y. H. (2020). Career competencies and perceived work performance. Journal of Asian Finance, Economics and Business, 7(6), 317-326. https://doi.org/10.13106/jafeb.2020. vol7.no6.317

Sidani, Y. M., \& Al Hakim, Z. T. (2012). Work-family conflicts and job attitudes of single women: A developing country perspective. International Journal of Human Resource Management, 23(7), 1376-1393. https://doi.org/10.1080/0958 5192.2011.579919

Sumaryati, A., Novitasari, E. P., \& Machmuddah, Z. (2020). Accounting Information System, Internal Control System, Human Resource Competency and Quality of Local Government Financial Statements in Indonesia. Journal of Asian Finance, Economics and Business, 7(10), 795-802. https://doi.org/10.13106/jafeb.2020.vol7.n10.795

Thomas, W. H. N., Lillian, T. E., Kelly, L. S., \& Daniel, C. F. (2005). Predictors of Objective and Subjective Career Success: a Meta-Analysis. Personnel Psychology, 58(2), 367. Retrieved from http://proquest.umi.com/pqdweb?did=851499911\&Fmt $=7 \&$ clientId $=12010 \&$ RQT $=309 \&$ VName $=$ PQD
Tomlinson, J., Baird, M., Berg, P., \& Cooper, R. (2018). Flexible careers across the life course: Advancing theory, research and practice. Human Relations, 71(1), 4-22. https://doi. org/10.1177/0018726717733313

Vinkenburg, C. J., \& Weber, T. (2012). Managerial career patterns: A review of the empirical evidence. Journal of Vocational Behavior, 80(3), 592-607. https://doi.org/10.1016/j. jvb.2012.02.001

Wilson, M. E., Liddell, D. L., Hirschy, A. S., \& Pasquesi, K. (2016). Professional identity, career commitment, and career entrenchment of midlevel student affairs professionals. Journal of College Student Development, 57(5), 557-572. https://doi. org/10.1353/csd.2016.0059

Yang, N.-Y., \& Han, S.-S. (2010). The Effect of Nurses' Competencies on career managemen and career commitment. Journal of Nursing Administration, 16(3), 286-294.

Zhang, T., Zhang, J., \& Li, C. (2018). A study of the employees' professional competency on career commitment towards work performance in ecology industry. Ekoloji, 27(106), 1785-1791. 